\title{
Nutritional Factors in Autism and Attention Deficit/Hyperactivity Disorder
}

\author{
Scott S Field
}

Paediatrician, Huntsville Hospital, University of Alabama in Birmingham (Huntsville Campus), USA

*Corresponding author: Scott S Field, Pediatrician, Huntsville Hospital, University of Alabama in Birmingham (Huntsville Campus), USA, Tel: 256-881-9355; 256-656-8819; E-mail: scottfieldmd@gmail.com

Rec date: 27 July 2014, Acc date: 09 Sep 2014, Pub date: 19 Sep 2014

Copyright: (C) 2014 Field SS, et al. This is an open-access article distributed under the terms of the Creative Commons Attribution License, which permits unrestricted use, distribution, and reproduction in any medium, provided the original author and source are credited.

\section{Short Communication}

Autism And Attention Deficit/Hyperactivity Disorder (ADHD) share multiple risk factors, most of which can be tied to omega-3 fatty acid metabolism and supplies of the end product, docosahexaenoic acid (DHA) for the developing brain. There has also been a significant rise in prevalence in both disorders in recent decades [1]. The following discussion addresses the potential role of DHA deficits in the etiology of autism and ADHD as well as the potential for prevention through improved diet and/or supplements to mothers and babies at higher risk.

Transport of DHA and its precursors from a mother to her children before birth and in the first year after birth is important for normal brain development [2]. Since DHA concentrations in fetal tissues rise sharply in the last two months of gestation and premature babies have lower levels than term babies, [3] prematurity limits DHA supplies for the developing brain. Prematurity is a well-known risk factor for autism and ADHD [4]

Apart from fish and algae-derived DHA supplements, almost all DHA for mothers and their babies has to come from conversion of the shorter chain, mainly plant-derived alpha-linolenic acid [5]. That conversion requires a series of enzymatic steps, but the rate limiting step involves the enzyme, Delta-6 Desaturase (D6D) which is enhanced by estrogen and inhibited by testosterone [6]. This hormonal effect results in females being born with more DHA at birth [7] and may explain why males are four times as likely as females to develop ADHD and autism [1,5]. Women lose DHA supplies during pregnancies [6,8]. Longer intervals (up to 3 years) between pregnancies and breastfeeding are helpful for replenishing lost DHA [8]. Indeed, close pregnancy spacing has been found to be a risk factor for autism [9]. Conversely, adequate child spacing along with breastfeeding is associated with increased maternal DHA stores [8] which may explain why being a first-born male is a risk factor even though subsequent children have older parents which is a competing risk factor [1].

Intrauterine transfer of DHA is also limited by gestational diabetes [10] which is a risk factor for both ADHD [11] and autism [12]. Another risk factor at least identified for autism [13] and perhaps also for ADHD [1] is advanced maternal age which is associated with decreased D6D activity [14]. Furthermore a Single Nucleotide Polymorphism (SNP) for the D6D gene which decreases enzyme activity has been shown to decrease DHA in breast milk [15]. That gene is associated with ADHD [16] and neighboring genes are associated with autism [14]. Thus both genes and diet can influence nutritional supplies of DHA for developing fetal and infant brains. In situations of advanced maternal age or defective D6D genes which might be reflected in maternal psychopathology such as maternal ADHD, supplemental DHA given to the mother during pregnancy and to the infant after birth may compensate for otherwise deficient maternal fetal transfer.Evidence that omega-3 fatty acids like DHA may be protective for autism include the lack of autism in an isolated community of Northern Quebec which had very high fish consumption [17] and the finding of more mercury in controls than in autism patients in a California study that attributed the higher mercury levels to greater fish consumption [18]. Lower blood levels of omega-3 fatty acids have been found in autism [19-21] and ADHD $[22,23]$ patients and some studies have found symptom improvements by using a combination of omega- 3 and omega- 6 fatty acids in supplemental trials [20,24-27]. Interestingly, trials using primarily DHA for supplementation have not shown benefit for symptoms $[28,29]$. A study that looked at risk of autism in relation to infant milk type found an increased risk with formula not supplemented with DHA compared to formula supplemented with DHA or breast milk [30].

An interesting finding in a British study [31] was an increased risk of autism in children of parents who had migrated from other countries. Fish consumption as a potential factor was not addressed, but their highest autism rates were in immigrants from the Caribbean Islands. In another study [1] a disproportionate number of children with at least one immigrant parent had autism, and all of them came from places where the parent said that fish was a prominent part of the diet while fish was no longer a prominent part of the diet where the child was born. What might explain this phenomenon of increased risk for autism in children of immigrant parents is that generations of people exposed to fish may have increased numbers of inefficient conversion enzyme genes because conversion is not as important in that population. When people with inefficient conversion enzymes and their children with the same inefficiencies are placed (by migration) in an environment in which they can't rely on their diet to provide the necessary long chained omega- 3 fatty acids, their brains are adversely affected with conditions like ADHD and/or autism.

Another dietary factor that can play into this is antioxidants from foods and supplements which are known to protect long-chain omega-3 fatty acids which are otherwise easily oxidized. Breath ethane, associated with omega-3 fatty acid oxidation was found in greater quantities in ADHD patients than controls [32].

Perhaps the most significant dietary finding in a recent clinical study [1] was that breastfeeding could reduce or enhance the risk for offspring developing ADHD and autism depending on variables of maternal age and maternal psychopathology. Psychopathology in that study included ADHD, autism, depression, schizophrenia, obsessive compulsive disorder, anxiety disorder, tic disorder, dyslexia, and bipolar disorder. Both ADHD and autism, in male and female children, occurred at significantly greater rates compared to controls if the mothers had psychopathology, breastfed, and were over 30 years old. If the mother did not have psychopathology, breastfeeding was protective against ADHD even when she was older than 30 years with 
Page 2 of 2

her first-born male. When neither parent had psychopathology, breastfeeding by older mothers was more $(\mathrm{p}<0.001)$ protective and breastfeeding by younger mothers was borderline $(\mathrm{P}<0.1)$ protective for ADHD. Larger studies are needed to corroborate the data of that study, but it makes sense that not all babies, mothers, and breast milk are alike, so it is wise to separate out factors that could cause differences. Considering such differences may change nutritional approaches to health problems associated with nutrition. Conditions such as ADHD and autism may be partially preventable by treating high risk individuals with healthier diets containing more fish, fruits, and vegetables as well as with nutritional supplements such as fish oil. More studies are needed.

\section{References}

1. Field SS (2014) Interaction of genes and nutritional factors in the etiology of autism and attention deficit/hyperactivity disorders: a case control study. Med Hypotheses 82: 654-661.

2. Sabel KG, Lundqvist-Persson C, Bona E, Petzold M, Standvik B (2009) Fatty acid patterns early after premature birth, simultaneously analysed in mothersâ food, breast milk and serum phospholipids of mothers and infants. Lipids Health Dis 8: 20.

3. Hornstra G (2000) Essential fatty acids in mothers and their neonates.Am J Clin Nutr 71: 1262S-9S.

4. Singh GK, Kenney MK, Ghandour RM, Kogan MD, Lu MC (2013) Mental Health Outcomes in US Children and Adolescents Born Prematurely or with Low Birthweight. Depress Res Treat 2013: 570743.

5. Richardson AJ (2006) Omega-3 fatty acids in ADHD and related neurodevelopmental disorders.Int Rev Psychiatry 18: 155-172.

6. Childs CE, Romeu-Nadal M, Burdge GC, Calder PC (2008) Gender differences in the n-3 fatty acid content of tissues. Proc Nutr Soc 67: 19-27.

7. $\mathrm{Al} \mathrm{MD}$, van Houwelingen $\mathrm{AC}$, Kester $\mathrm{AD}$, Hasaart TH, de Jong AE, et al. (1995) Maternal essential fatty acid patterns during normal pregnancy and their relationship to the neonatal essential fatty acid status. Br J Nutr 74: 55-68.

8. Bonham MP, Duffy EM, Wallace JM, Robson PJ, Myers GJ, et al. (2008) Habitual fish consumption does not prevent a decrease in LCPUFA status in pregnant women (the Seychelles Child Development Nutrition Study). Prostaglandins Leukot Essent Fatty Acids 78: 343-350.

9. Cheslack-Postava K, Liu K, Bearman PS (2011) Closely spaced pregnancies are associated with increased odds of autism in California sibling births. Pediatrics 127: 246-253.

10. Larqué E, Demmelmair H, Gil-Sánchez A, Prieto-Sánchez MT, Blanco JE, et al. (2011) Placental transfer of fatty acids and fetal implications. Am J Clin Nutr 94: 1908S-1913S.

11. Schmitt J, Romanos M (2012) Prenatal and perinatal risk factors for attention-deficit/hyperactivity disorder. Arch Pediatr Adolesc Med 166: 1074-1075.

12. Lyall K, Pauls DL, Spiegelman D, Ascherio A, Santangelo SL (2012) Pregnancy complications and obstetric suboptimality in association with autism spectrum disorders in children of the Nurses' Health Study II. Autism Res 5: 21-30.

13. Shelton JF, Tancredi DJ, Hertz-Picciotto I (2010) Independent and dependent contributions of advanced maternal and paternal ages to autism risk. Autism Res 3: 30-39.

14. Horrobin DF, Benett CN (1999) New gene targes related to schizophrenia and other psychiatric disorders: enzymes, binding proteins and transport proteins involved in phospholipid and fatty acid metabolism. Prostaglandins Leukot Essent Fatty Acids 60: 141-167.
15. Xie L, Innis SM (2008) Genetic variants of the FADS1 FADS2 gene cluster are associated with altered (n-6) and (n-3) essential fatty acids in plasma and erythrocyte phospholipids in women during pregnancy and in breast milk during lactation. J Nutr 138: 2222-2228.

16. Brookes KJ, Chen W, Xu X, Taylor E, Asherson P (2006) Association of fatty acid desaturase genes with attention-deficit/hyperactivity disorder. Biol Psychiatry 60: 1053-1061.

17. Fombonne E, Morel J, Macarthur J (2006) No autism amongst Inuits from northern Quebec? Fifth International Meeting for Autism Research (Abstract PS 6.4).

18. Hertz-Picciotto I, Green PG, Delwiche L, Hansen R, Walker C, et al. (2010) Blood mercury concentrations in CHARGE Study children with and without autism. Environ Health Perspect 118: 161-166.

19. Bell JG, MacKinlay EE, Dick JR, MacDonald DJ, Boyle RM, et al. (2004) Essential fatty acids and phospholipase A2 in autistic spectrum disorders. Prostaglandins Leukot Essent Fatty Acids 71: 201-204.

20. Meguid NA, Atta HM, Gouda AS, Khalil RO (2008) Role of polyunsaturated fatty acids in the management of Egyptian children with autism. Clin Biochem 41: 1044-1048.

21. Wiest MM, German JB, Harvey DJ, Watkins SM, Hertz-Picciotto I (2009) Plasma fatty acid profiles in autism: a case-control study. Prostaglandins Leukot Essent Fatty Acids 80: 221-227.

22. Mitchell EA, Aman MG, Turbott SH, Manku M (1987) Clinical characteristics and serum essential fatty acid levels in hyperactive children. Clin Pediatr (Phila) 26: 406-411.

23. Stevens LJ, Zentall SS, Abate ML, Kuczek T, Burgess JR (1996) Omega-3 fatty acids in boys with behavior, learning, and health problems. Physiol Behav 59: 915-920.

24. Meiri G, Bichovsky Y, Belmaker RH (2009) Omega 3 fatty acid treatment in autism. J Child Adolesc Psychopharmacol 19: 449-451.

25. Amminger GP, Berger GE, Schäfer MR, Klier C, Friedrich $M H$, et al. (2007) Omega-3 fatty acids supplementation in children with autism: a double-blind randomized, placebo-controlled pilot study. Biol Psychiatry 61: 551-553.

26. Johnson M, Ostlund S, Fransson G, Kadesjö B, Gillberg C (2009) Omega-3/omega-6 fatty acids for attention deficit hyperactivity disorder: a randomized placebo-controlled trial in children and adolescents. J Atten Disord 12: 394-401.

27. Richardson AJ, Montgomery P (2005) The Oxford-Durham study: a randomized, controlled trial of dietary supplementation with fatty acids in children with developmental coordination disorder. Pediatrics 115: 1360-1366.

28. Voigt RG, Llorente AM, Jensen CL, Fraley JK, Berretta MC, et al. (2001) A randomized, double-blind, placebo-controlled trial of docosahexaenoic acid supplementation in children with attention-deficit/hyperactivity disorder. J Pediatr 139: 189-196.

29. Hirayama S, Hamazaki T, Terasawa K (2004) Effect of docosahexaenoic acid-containing food administration on symptoms of attention-deficit/ hyperactivity disorder - a placebo-controlled double-blind study. Eur J Clin Nutr 58: 467-473.

30. Schultz ST, Klonoff-Cohen HS, Wingard DL, Akshoomoff NA, Macera CA, et al. (2006) Breastfeeding, infant formula supplementation, and Autistic Disorder: the results of a parent survey. Int Breastfeed J 1: 16.

31. Keen DV, Reid FD, Arnone D (2010) Autism, ethnicity and maternal immigration. Br J Psychiatry 196: 274-281.

32. Ross BM, McKenzie I, Glen I, Bennett CP (2003) Increased levels of ethane, a non-invasive marker of n-3 fatty acid oxidation, in breath of children with attention deficit hyperactivity disorder. Nutr Neurosci 6: 277-281. 